\title{
"Spillover effects between Greece and Cyprus: a DCC model on the interdependence of small economies"
}

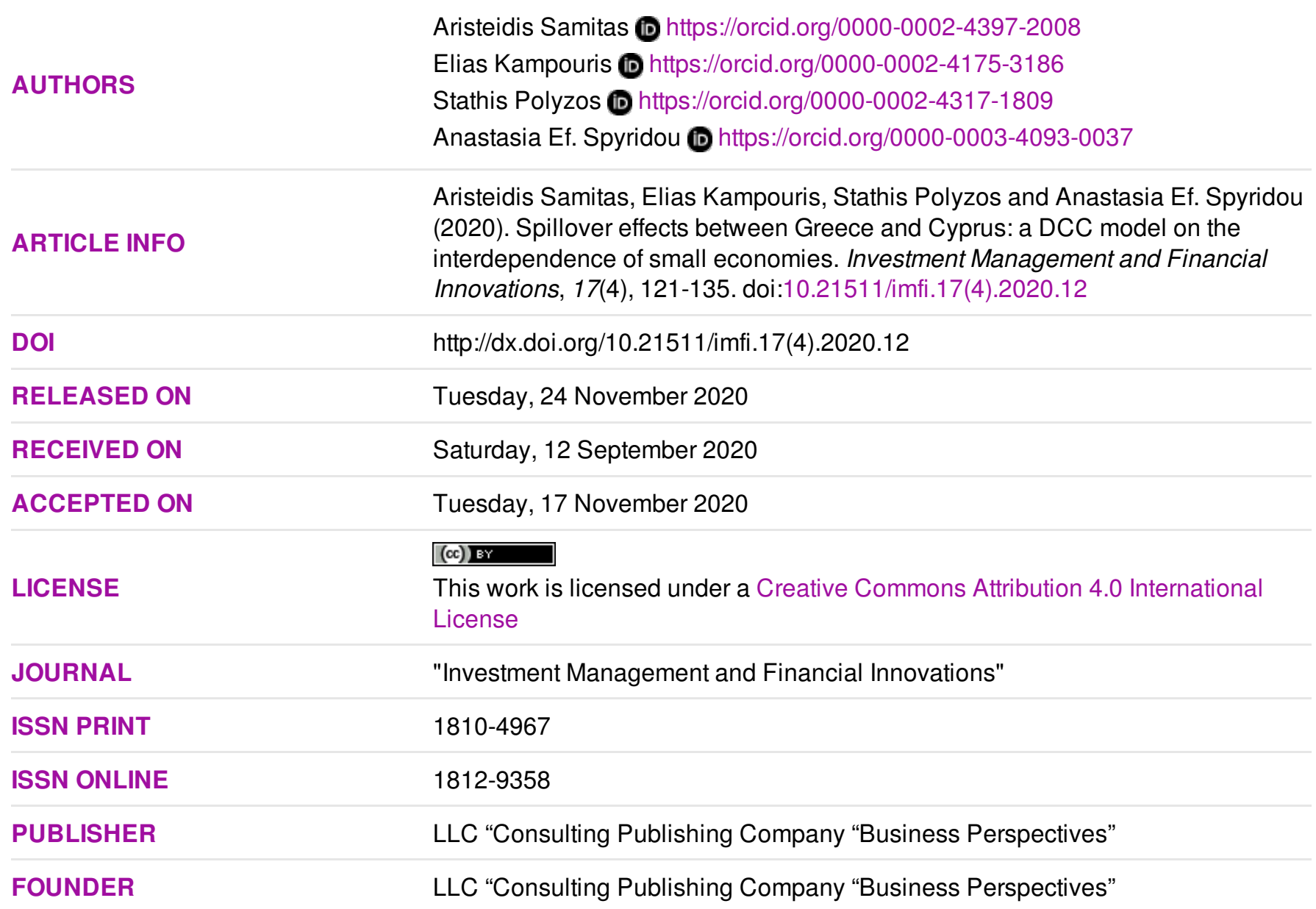

NUMBER OF REFERENCES

53

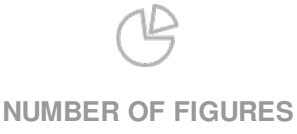

10
$-=-$
$-=-$

NUMBER OF TABLES

2

C The author(s) 2021. This publication is an open access article. 


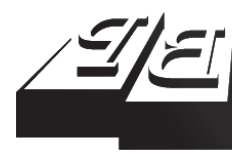

BUSINESS PERSPECTIVES

(O)

LLC "CPC "Business Perspectives" Hryhorii Skovoroda lane, 10, Sumy, 40022, Ukraine www.businessperspectives.org
Received on: $22^{\text {nd }}$ of September, 2020 Accepted on: 17th of November, 2020 Published on: $24^{\text {th }}$ of November, 2020

(c) Aristeidis Samitas, Elias Kampouris, Stathis Polyzos, Anastasia Ef. Spyridou, 2020

Aristeidis Samitas, Ph.D., Professor, Department of Finance, College of Business, Zayed University, Abu Dhabi, UAE

Elias Kampouris, Ph.D., Assistant Professor, College of Business Administration, Abu Dhabi University Al Ain, UAE.

Stathis Polyzos, Ph.D., Assistant Professor, College of Business, Zayed University, Abu Dhabi, UAE (Corresponding author)

Anastasia Ef. Spyridou, Ph.D. Candidate, Faculty of Management and Economics, Gdansk University of Technology, Gdansk, Poland.

Aristeidis Samitas (UAE), Elias Kampouris (UAE), Stathis Polyzos (UAE), Anastasia Ef. Spyridou (Poland)

\title{
SPILLOVER EFFECTS BETWEEN GREECE AND CYPRUS: A DCC MODEL ON THE INTERDEPENDENCE OF SMALL ECONOMIES
}

\begin{abstract}
This paper discusses the volatility spillovers between the Greek debt crisis and the Cypriot financial crisis. Cyprus was in the spotlight of financial markets due to significant problems stemming from the banking sector, which were dealt with by EU regulators with a bail-in on bank deposits. The current analysis aims to shed light on the reasons behind implementing this novel approach to bank distress. The study uses a Dynamic Conditional Correlation model on the returns of the stock markets of the two countries, which shows strong spillover effects during the period leading up to the 2013 Cypriot crisis, but a significant decrease of these effects from then on. The results confirm the close interdependence of the Greek and Cypriot economies before 2013 and show that this interdependence was limited from that point onwards. This would indicate that since the risk of contagion to the Eurozone had diminished, regulators could test the bail-in solution in Cyprus in 2015. The current work contributes to the discussion on the interdependence of European economies. The paper's findings can also be applied to other emerging European economies.
\end{abstract}

\section{Keywords}

JEL Classification

\section{INTRODUCTION}

The 2008 Great Financial Crisis (GFC) triggered an unexpected worldwide turmoil and resulted in a series of economic shocks. International markets experienced a new economic framework, the consequences of which permanently changed the financial sector. During this turbulent period, Cyprus was forced to implement a new banking practice, bail-in, after suffering significant negative spillovers from the Greek debt crisis, which started in 2010. Under the pressure of its European partners, the Cypriot government was forced to levy all bank deposits above EUR 100,000 by $40 \%$.

The current study aims to measure, quantify, and compare the co-movements between the Greek debt crisis and the Cypriot financial crisis. Besides, the paper tries to examine whether there exists a strong contagion phenomenon between these two economies. To achieve this, Engle's Dynamic Conditional Correlation (DCC) model (Engle, 2002) is employed, which is better suited to measure volatility in asymmetric data (Castagneto-Gissey \& Nivorozhkin, 2016). The present work aims to show that the bail-in solution was implemented in Cyprus only after authorities had ensured that any financial distress would not be transmitted to the rest of Europe. 
This is because the interdependence between Cyprus and Greece, its main trading partner in the EU, was significantly limited.

This paper contributes to three aspects of the relevant literature. First, it demonstrates how the DCC model can be used to quantify the volatility spillovers between two economies. Second, the paper investigates the relationships and the covariance between the stock markets of two developing EU economies, namely Greece and Cyprus. Third, the current research examines the contagion outcome of implementing the bail-in solution in a Eurozone economy.

\section{LITERATURE REVIEW}

Research on measuring cross-market dependence, correlations between stock markets, or financial contagion is not new but can be traced back to the past. Financial contagion is commonly defined as negative shocks or spillovers transmitted across countries, especially during crisis. In terms of policy responses, spillover effects are important in evaluating the applicability of authorities' different measures. Castagneto-Gissey and Nivorozhkin (2016) examine the transmission paths from the Russian stock market to 18 major global markets after implementing the 2014-2015 sanctions against Russia. They find limited evidence of negative spillovers in returns and present volatility spillovers, particularly in emerging economies.

The first efforts to study the contagion effect confirmed its existence after a financial crash (Calvo \& Reinhart, 1996; Lee \& Kim, 1993; King \& Wadhwani, 1990). There is an ongoing debate on this phenomenon since some researchers confirm the increased correlation following financial crises, while others present doubts. The Asian crisis was the first widely examined case of international contagion, albeit regional. Dungey and Martin (2007) confirmed volatility co-movements among the Asian economies in both the stock and the currency markets. Similarly, Huidrom et al. (2017) find spillover effects among emerging markets using a vector autoregressive model. On the other hand, Corsetti et al. (2005) find evidence that financial contagion in other markets does not exist in their sample.

Zhou and Gao (2010) analyze the tail dependence of six major real estate securities markets to monitor the co-movements using Symmetrized Joe-Clayton (SJC) copula. The results showed that these six markets display varying tail dependence in terms of intensity and dynamics. McDonald et al. (2015) construct financial stress indices for Eurozone countries by implementing multivariate analysis (VAR models). In this manner, they can model the interactions between the root causes of systemic risk in the Eurozone. They find that systemic risk in the sample economies is mostly responsive to own-country financial shocks, even though shocks from neighboring countries may also be propagated to a certain extent. Polyzos et al. (2018) show that systemic risk could also stem from governance issues related to each banking institution. On the other hand, Zimmer (2014) proposes a copula-based approach to model co-movements in house prices and finds that conflicting results between the US and other OECD countries. He shows that US house prices in different areas exhibit simultaneous co-movements, while this is not true for the rest of the world. In general, the literature recognizes relationships in financial markets as non-linear (Anufriev et al., 2018). Pantos et al. (2019) show that volatility spillovers are also present in electricity markets.

Even though a wide range of methodologies has been used, economists do not seem to agree on a single empirical procedure to identify contagion. Several studies try to model the various channels that may transmit the spread and quantify contagion using various econometric techniques. Among these techniques, Engle (2002) proposes the dynamic conditional correlation Generalized Autoregressive Conditional Heteroscedasticity (DCC-GARCH) model to overcome the limitations of previous methodologies on financial contagion. The main issue is the heteroscedasticity problem when estimating the time-varying conditional correlations. Several other authors attempt to extend this methodology and propose various modifications (Aielli, 2013; Samitas et al., 2020; 
Cho \& Parhizgari, 2009; M. Pesaran \& B. Pesaran, 2007; Cappiello et al., 2006; Rigobon \& Sack, 2003; Billio \& Pelizzon, 2003).

Following the GFC period in 2008, many recent studies use dynamic conditional correlations to examine financial contagion. Hwang (2014) employs a DCC-GARCH model to examine the transmission of the negative effects of GFC from the US to four Latin American stock markets and confirm the contagion effect, as attested by the increased magnitude and volatility of conditional correlations during the GFC period. B. Kim and S. Kim (2013) also test for negative spillovers of the GFC towards Korea and other neighboring financial markets using DCC-GARCH. They demonstrate that the GFC shocks were transmitted domestic financial markets (increased correlation coefficients) and further weakened them. Ahmad et al. (2013) use dynamic conditional correlations and examine the financial contagion of PIIGS ${ }^{1}$ on BRIICKS ${ }^{2}$ countries. The results indicate a contagion effect, both from BRIICKS to PIIGS and vice versa, albeit not among all the countries in the sample.

Following the same framework, Kenourgios and Dimitriou (2014) and Karanasos et al. (2016) propose the FIAPARCH-DCC model to test for possible contagion effects of the GFC. Both studies find significant spillover effects and volatility dependence across neighboring stock markets and among regional financial and non-financial sectors. However, Dimitriou et al. (2013) study BRIICs using the FIAPARCH-DCC methodology and cannot find any specific pattern of contagion.

Among other studies that use dynamic conditional correlations to test for financial contagion, Anastasopoulos (2018) examines contagion effects from the Greek debt crisis and the Yuan devaluation on key trading partners and finds limited persistent effects in the Greek case. Petmezas and Santamaria (2014) investigate crisis transmission, both locally and internationally, by analyzing stock-bond relationships in the US and the EU before and during the GFC and the European Debt Crisis (EDC) of 2007-2012. Their findings suggest that the wealth effect could be the main source of contagion. Similarly, Hemche et al. (2016) investigate the contagion hypothesis between the US and 10 different stock markets during the GFC period. They show dynamic correlations between the US and most markets in their sample increased after the GFC. Several other studies follow Engle's (2002) methodology and other variations of multivariate GARCH models to test for financial contagion (Sikhosana \& Aye, 2018; Rajwani \& Kumar, 2015; Bekiros, 2014; Wang, 2013; Celik, 2012).

Some studies also take into account the Greek crisis. Tamakoshi and Hamori (2013) employ an asymmetric DCC model on five significant banking institutions in Europe, exposed to Greek sovereign bonds. They find a significant burst in time-varying correlations between the returns of these banks' shares in the period following the EDC period. Following the same framework, Kenourgios (2014) studies both US and European stock markets during the GFC and the EDC in terms of volatility contagion. The results indicate the existence of contagion in cross-market volatilities, which are significantly increased during these periods. The DCC approach has also been used by numerous other researchers when examining contagion during the GFC and the EDC (Chiang et al., 2014; Kazi \& Wagan, 2014; Liow, 2012).

\section{METHODS}

\subsection{Data}

To measure the conditional correlations between Greece and Cyprus and present the significance of the evidence, the data must first be split into two major subgroups. The sample is divided into two periods. The first period covers the 2008 Global Financial Crisis (GFC) and the second the Eurozone Debt Crisis (EDC). The GFC covers the period from 4 January 2005 up to 31 December 2009, while the EDC period includes the dates from 4 January 2010 until 30 June 2015, which is the date that the Greek capital market closed after the enforcement of capital controls (see Samitas \& Polyzos, 2016 for a more detailed discussion).

\footnotetext{
1 PIIGS countries: Portugal, Italy, Ireland, Greece, and Spain.

2 BRIICKS countries: Brazil, Russia, India, Indonesia, China, South Korea, and South Africa.
} 
Furthermore, the sample contains daily returns of stocks indices from the Greek and the Cypriot market. It is considered that the EDC period was an internal issue for Greece and Cyprus and not a Eurozone problem. Major banks, credit rating institutions, and Eurozone members determined this problem as an individual problem of Greece and Cyprus, which later became a Eurozone problem despite their expectations.

\subsection{Methodology}

The paper uses the DCC model of Engle (2002) to test the behavior of correlations between the Greek and the Cypriot stock markets. A major advantage of this model is the ability to test for dependence in different time series. Until now, the literature includes a variety of models to investigate the contagion phenomenon and spillover effects. The literature review shows that in most cases, the DCC model permits researchers to obtain robust results, particularly when there are asymmetries in the data. The DCC model is an appropriate specification for quantifying the interdependence among markets because it is flexible and allows time-varying correlations and covariance matrixes.

Engle (2002) proposes the Dynamic Conditional Correlation (DCC) model, which he presented as a generalization of Bollerslev's Constant Conditional Correlation (CCC) model (Bollerslev, 1990). The covariance matrix $H_{t}$ of Bollerslev's model has the following form:

$$
H_{t}=D_{t} R_{t} D_{t} \text {, }
$$

where $D_{t}=\operatorname{diag}\left\{\sqrt{h_{i, t}}\right\}$ is the diagonal matrix of the conditional standard deviations and $R_{t}=\left\{\rho_{i, j, t}\right\}$ is the correlation matrix. The expressions $h$ are estimated with univariate GARCH models for each return series. In this paper, the Glosten-Jagannathan-Runkle GARCH (GJRGARCH) model of Glosten et al. (1993) is employed. The GJR-GARCH model is appropriate for capturing any asymmetry and excess kurtosis in the data, particularly when indices fail the assumptions of normal distribution. The GJRGARCH model assumes the following form:

$$
\sigma_{t}^{2}=\omega+\left(\alpha+\gamma I_{t-1}\right) \varepsilon_{t-1}^{2}+\beta \sigma_{t-1}^{2},
$$

where $I_{t-1}=\left\{\begin{array}{lll}0 & \text { if } \quad r_{t-1} \geq \mu \\ 1 & \text { if } \quad r_{t-1}<\mu\end{array}\right.$

and $\alpha \geq 0, \beta \geq 0, \omega>0$.

Many authors support the assumption that the GJR-GARCH model captures the increased impact on variance at time $t$ of negative shocks at time $t-1$ compared to positive shocks. This asymmetry is known as the leverage effect. The negative shock produces increased risk, and this means that this particular model can capture a higher number of lags in conditional variance [GJR-GARCH $(p, q)]$ :

$$
\sigma_{t}^{2}=\omega+\sum_{i=1}^{p}\left(\alpha+\gamma I_{t-1}\right) \varepsilon_{t-1}^{2}+\sum_{j=1}^{q} \beta \sigma_{t-1}^{2} .
$$

The suggestion here is to model $\varepsilon_{t}=\sigma_{t} z_{t}$, where $z_{t}$ is i.i.d. The best model is selected using the Bayesian Information Criterion (BIC) and Akaike Information Criterion (AIC). The DCC model differs only in allowing $R_{t}$ being time-varying. Therefore, Engle's DCC model is expressed as follows:

$$
H_{t}=D_{t} R_{t} D_{t} \text {, }
$$

$$
\begin{aligned}
& \text { where } R_{t}=\left(Q_{t}^{*}\right)^{-1} Q_{t}\left(Q_{t}^{*}\right)^{-1} \\
& \text { and } Q_{t}=[1-\alpha(1)-\beta(1)] \Gamma+ \\
& +\alpha(L) \eta_{t-1} \eta_{t-1}^{\prime}+\beta(L) Q_{t-1},
\end{aligned}
$$

where $\alpha$ and $\beta$ are the scalar parameters like an ordinary GARCH model. $Q_{t}^{*}$ is a diagonal matrix with a square root of the $i^{\text {th }}$ diagonal of $Q_{t}$ on its $i^{t h}$ diagonal position. Namely, in the $Q_{t}$ matrix, the model estimates the elements of correlations calculated by the coefficients. As discussed in Engle (2002), the $R$ parameterizations have the same requirements as those of $H$, with the exception that the conditional variances must be at unity. This methodology enables researchers to quantify the dependence between the two crises and the other markets. This model is quite familiar and useful in quantifying the dependence and the contagion phenomenon used by many authors (Jithendranathan, 2005; Gupta \& Donleavy, 2009; Gjika \& Horváth, 2013) because it captures time-varying conditional correlations between financial indices. 


\section{RESULTS}

\subsection{Descriptive statistics}

The summary statistics of the data are demonstrated in Table 1. Both indices (Greece and Cyprus) are negatively skewed in the GFC period, while they are positively skewed in the EDC period. Likewise, both indices have kurtosis higher than 3 in the GFC period. However, in the EDC period, only Cyprus exceeds kurtosis higher than 3, while the Greek index scores 2.7289. In both periods, the Cyprus market demonstrates the lowest and highest average returns. However, at the same time, this market demonstrates the highest volatility, as attested by the increased values in standard deviation. The Jarque-Bera test statistic shows that neither of the two indices is normally distributed.
Consequently, based on these preliminary findings, an AR(1)-GJR-GARCH model is apposite to capture asymmetry and excess kurtosis in both indices. Furthermore, both indices exhibit ARCH effects, with the null hypothesis that no ARCH effect is rejected uniformly for up to 5 lags.

\subsection{Empirical results}

The estimations of the DCC model are presented in Table 2 and Table 3 in a two-stage process. Table 2 presents the univariate estimations $\operatorname{AR}(1)$ - GJR GARCH $(1,1)$ for both indices. The $g$ coefficient, which shows the leverage effect, is significant only in the case of Greece in the GFC period. This guarantees the absence of normality in the index. However, in all other cases, the absence of normality is not strong enough.

Table 1. Descriptive statistics - Global Financial Crisis and Eurozone Debt Crisis

\begin{tabular}{|c|c|c|c|c|}
\hline \multirow{2}{*}{ Statistic } & \multicolumn{2}{|c|}{ GFC period } & \multicolumn{2}{|c|}{ EDC period } \\
\hline & Greece & Cyprus & Greece & Cyprus \\
\hline Mean & -0.0003 & 0.0004 & -0.0009 & -0.0021 \\
\hline Maximum & 0.1028 & 0.1212 & 0.1637 & 0.1696 \\
\hline Minimum & -0.0980 & -0.1214 & -0.1384 & -0.1553 \\
\hline Std. Dev. & 0.0186 & 0.0237 & 0.0273 & 0.0305 \\
\hline Skewness & -0.2176 & -0.0576 & 0.2332 & 0.2248 \\
\hline Kurtosis & 4.3864 & 3.7505 & 2.7289 & 4.5761 \\
\hline Jarque-Bera & 983.62 & 712.78 & 423.16 & 1167.2 \\
\hline Probability & {$[0.0000]$} & {$[0.0000]$} & {$[0.0000]$} & [0.0000] \\
\hline Observations & 1215 & 1215 & 1325 & 1325 \\
\hline \multirow{2}{*}{$\mathrm{ARCH}(5)$ test } & 51.612 & 28.992 & 11.055 & 15.993 \\
\hline & {$[0.0000]$} & {$[0.0000]$} & {$[0.0000]$} & [0.0000] \\
\hline
\end{tabular}

Table 2. Univariate estimations AR(1) - GJR GARCH $(1,1)$

\begin{tabular}{|c|c|c|c|c|c|c|c|c|}
\hline \multicolumn{9}{|c|}{ GFC period } \\
\hline \multirow{2}{*}{ Model } & \multicolumn{4}{|c|}{ Greece } & \multicolumn{4}{|c|}{ Cyprus } \\
\hline & Coefficient & Std. Error & $t$-value & $t$-prob & Coefficient & Std. Error & $t$-value & $t$-prob \\
\hline $\operatorname{Cst}(\mathrm{M})$ & 0.0004 & 0.0004 & 1.080 & 0.2802 & 0.0016 & 0.0005 & 3.341 & 0.0009 \\
\hline$A R(1)$ & 0.0891 & 0.0299 & 2.975 & 0.0030 & 0.1163 & 0.0311 & 3.741 & 0.0002 \\
\hline $\operatorname{Cst}(\omega)$ & 0.0359 & 0.0142 & 2.524 & 0.0117 & 0.0518 & 0.0373 & 1.389 & 0.1650 \\
\hline ARCH(Alpha1) & 0.0482 & 0.0174 & 2.770 & 0.0057 & 0.0905 & 0.0279 & 3.242 & 0.0012 \\
\hline GARCH(Beta1) & 0.8770 & 0.0236 & 37.080 & 0.0000 & 0.8745 & 0.0420 & 20.81 & 0.0000 \\
\hline GJR(Gamma1) & 0.1276 & 0.0360 & 3.543 & 0.0004 & 0.0685 & 0.0508 & 1.348 & 0.1778 \\
\hline \multicolumn{9}{|c|}{ EDC period } \\
\hline \multirow{2}{*}{ Model } & \multicolumn{4}{|c|}{ Greece } & \multicolumn{4}{|c|}{ Cyprus } \\
\hline & Coefficient & Std. Error & $t$-value & $t$-prob & Coefficient & Std. Error & $t$-value & $t$-prob \\
\hline $\operatorname{Cst}(M)$ & -0.0005 & 0.0007 & -0.720 & 0.4714 & -0.0005 & 0.0003 & -1.491 & 0.1362 \\
\hline$A R(1)$ & 0.0458 & 0.0334 & 1.372 & 0.1703 & 0.1630 & 0.0461 & 3.535 & 0.0004 \\
\hline $\operatorname{Cst}(\omega)$ & 0.1620 & 0.1025 & 1.581 & 0.1142 & 0.0078 & 0.0057 & 1.366 & 0.1721 \\
\hline $\mathrm{ARCH}($ Alpha1) & 0.0496 & 0.0239 & 2.078 & 0.0379 & 0.2131 & 0.0531 & 4.011 & 0.0001 \\
\hline GARCH(Beta1) & 0.9111 & 0.0310 & 29.360 & 0.0000 & 0.8667 & 0.0169 & 51.14 & 0.0000 \\
\hline GJR(Gamma1) & 0.0389 & 0.0292 & 1.333 & 0.1829 & -0.0827 & 0.0634 & -1.304 & 0.1924 \\
\hline
\end{tabular}




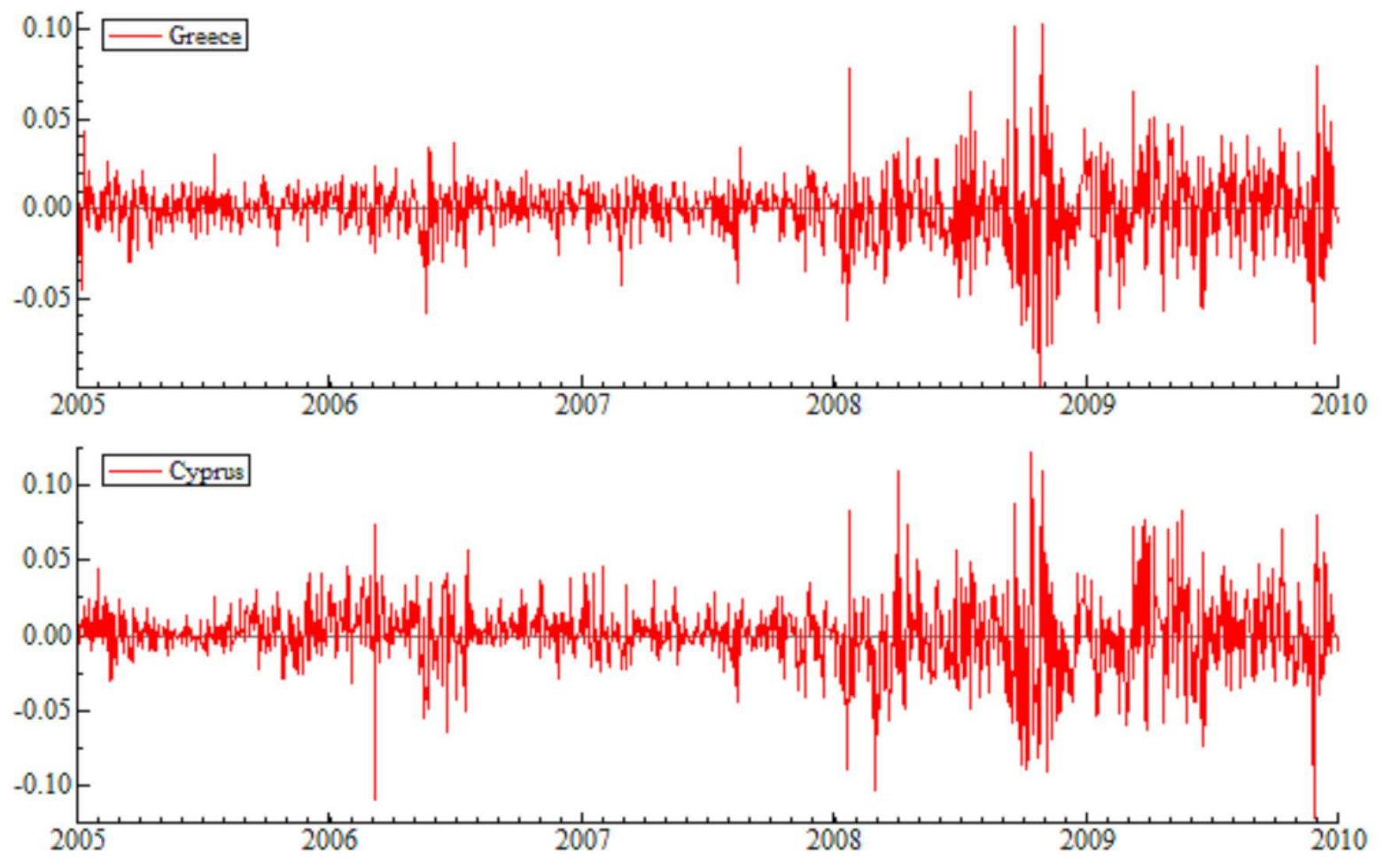

Figure 1. Stock market returns (GFC period)
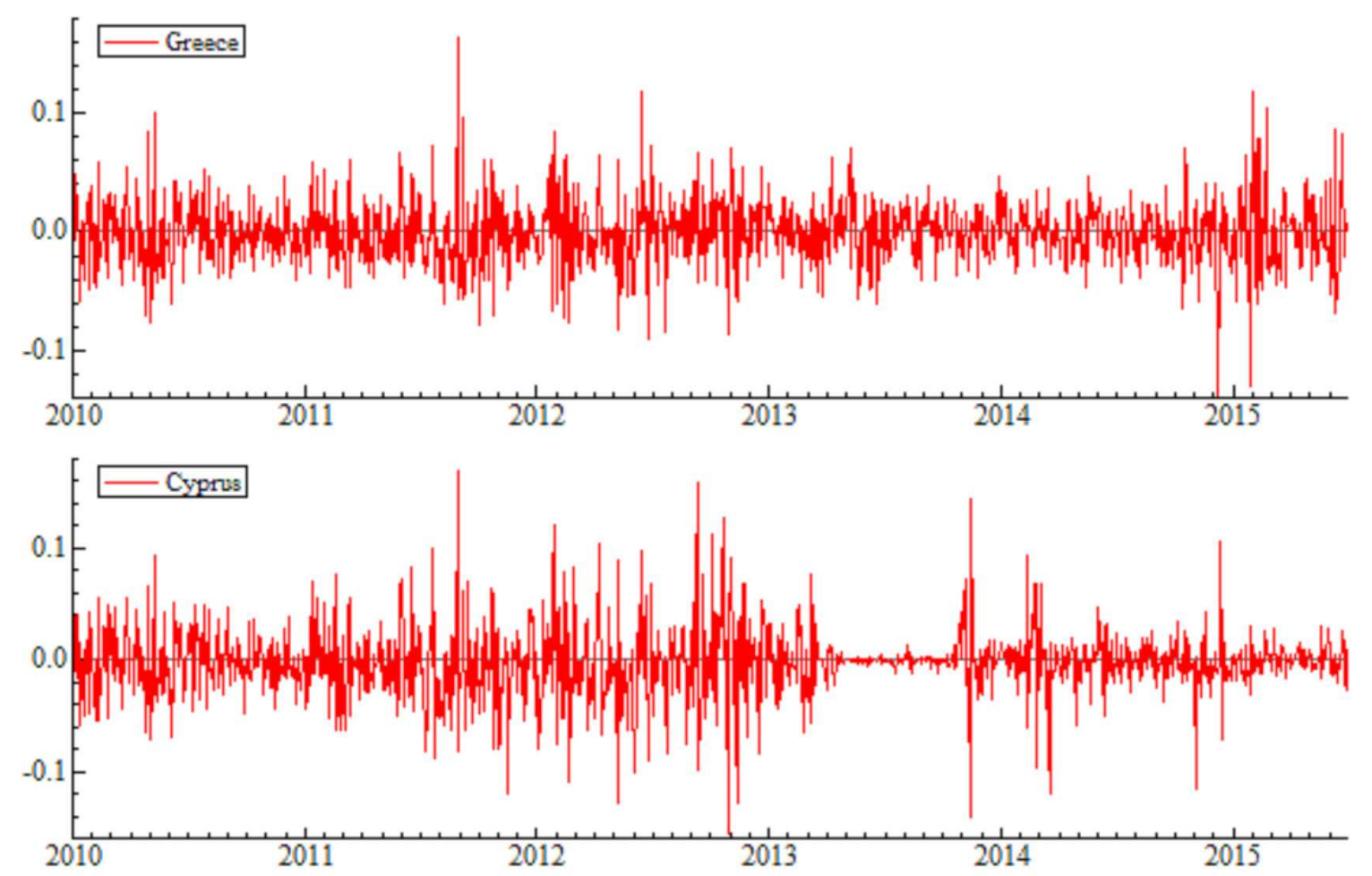

Figure 2. Stock market returns (EDC period) 

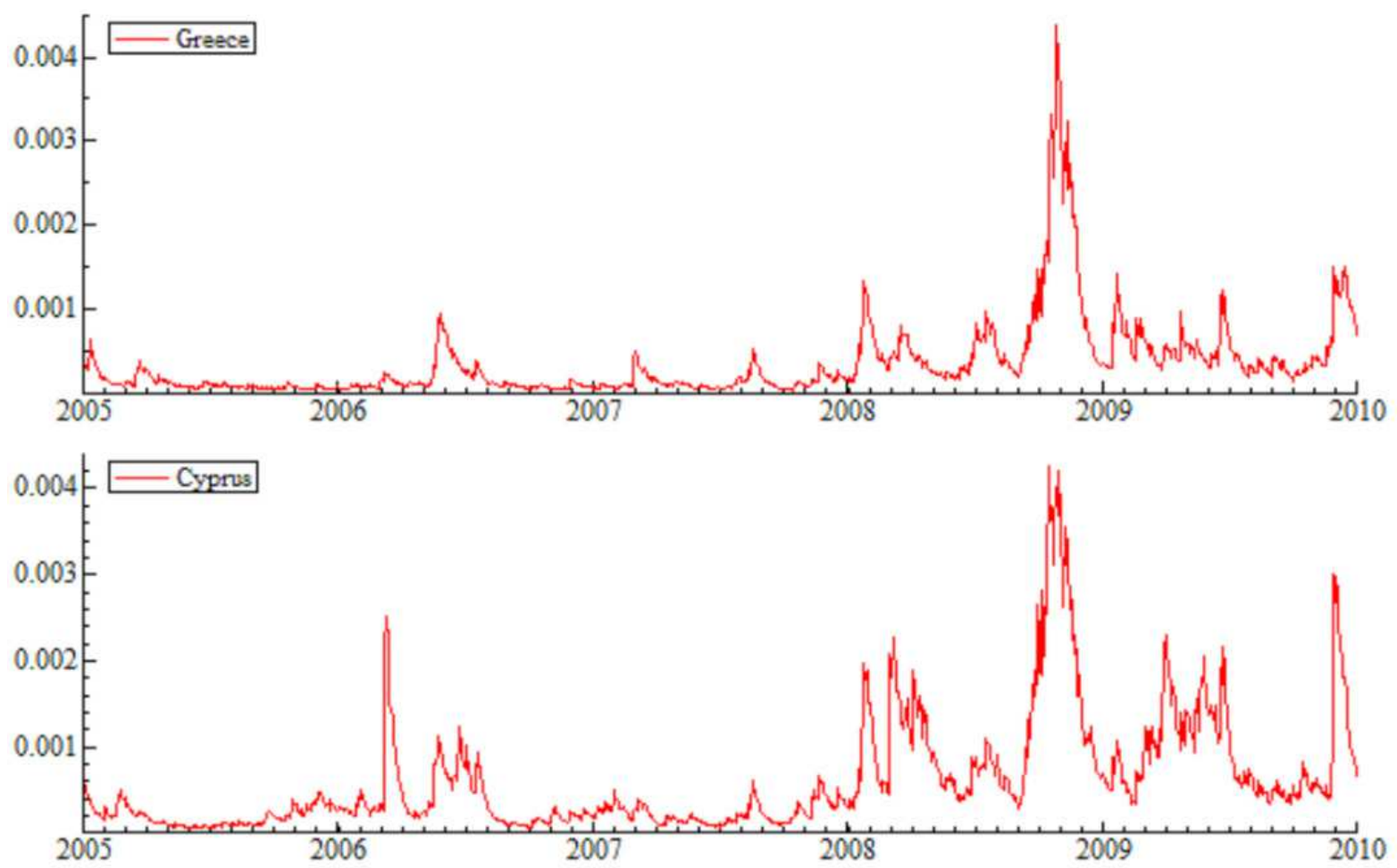

Figure 3. Univariate conditional variances (GFC period)
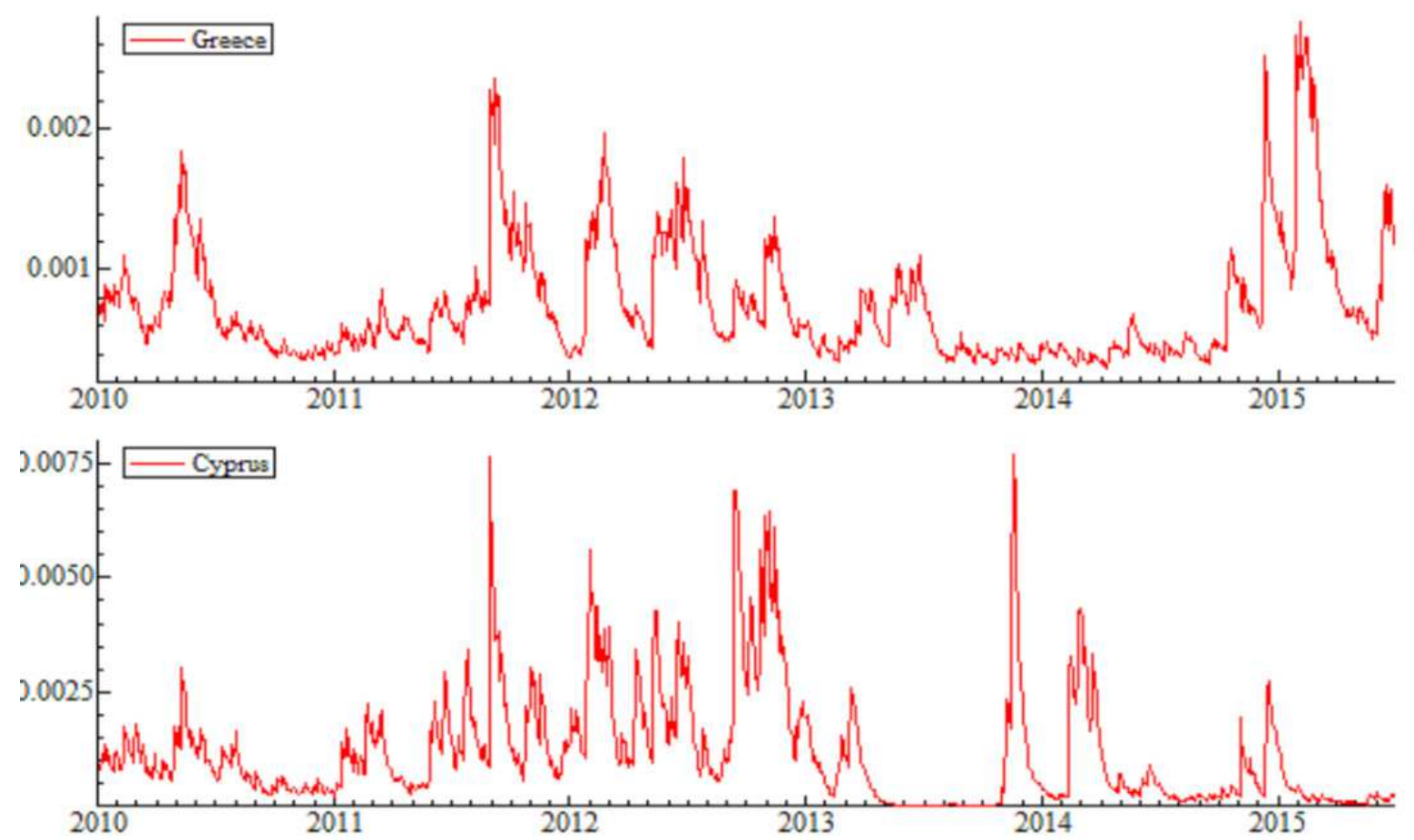

Figure 4. Univariate conditional variances (EDC period) 
Table 3. Dynamic conditional correlations (Greece - Cyprus)

\begin{tabular}{|c|c|c|c|c|}
\hline \multicolumn{5}{|c|}{ GFC period } \\
\hline Statistic & Coefficient & Std. Error & $t$-value & $t$-prob \\
\hline Uncon. Corr & 0.0464 & 0.7101 & 0.065 & 0.9479 \\
\hline Alpha & 0.0604 & 0.0173 & 3.494 & 0.0005 \\
\hline Beta & 0.9378 & 0.0187 & 50.260 & 0.0000 \\
\hline \multicolumn{5}{|c|}{ EDC period } \\
\hline Uncon. Corr & 0.8834 & 0.0624 & 14.160 & 0.0000 \\
\hline Alpha & 0.0328 & 0.0087 & 3.773 & 0.0002 \\
\hline Beta & 0.9672 & 0.0106 & 91.400 & 0.0000 \\
\hline
\end{tabular}

Figures 1 and 2 show the stock market returns for both countries, for the GFC and the EDC periods. Additionally, Figures 3 and 4 show the univariate conditional variance for each index, again for each period. It is clear from these last two graphs that there exists significantly increased volatility from the outbreak of the GFC in mid-2008 until mid-2013 when things seem to calm down. However, there is a spike of increased volatility in 2015 for Greece, which experiences political instability at that time.

Table 3 shows the dynamic conditional correlations of the two stock markets. The unconditional correlation is statistically significant only in the case of the EDC period (0.883). The ARCH parameter $a$ was higher in the GFC period (0.06), which means that shocks were significantly stronger in the first period than in the second (0.034). On the other hand, the GARCH parameter $\beta$ was higher in the EDC period, which shows the extent of increased volatility in the market. It is evident that if terms $a$ and $b$ are positive, and their sum is lower than one $(a+b<1)$, this implies dynamic conditional correlations. As can be seen, the results support the existence of correlations over time and a contagion effect. Furthermore, the analysis shows a significant increase during the crash period among the indices.

The descriptive statistics of the conditional correlations are presented in Table 4. The average conditional correlation is marginally lower in the EDC period (0.5066). However, the standard deviation is higher in the second period (0.3512). In all estimations, indices are negatively skewed and platykurtic, while the Jarque-Bera test ensures the absence of normality in correlations for both periods. Lastly, the GFC period shows lower maximum correlation values and higher minimums compared to the EDC period.

Covariances and conditional correlations are presented graphically in Figures 5 to 10 for each period separately. Both metrics support the paper's assertions that there exists a close connection between the two economies from 2008 to 2013, the period that includes the GFC and the subsequent crisis first in Greece (2010) and then in Cyprus (2012-2013), but this connection is limited after the implementation of the bail-in in Cyprus.

In the case of conditional correlation for the GFC period (Figure 7), the values start from the negative region but display an upward trend until the peak value of 0.80 . However, in the EDC period (Figure 8), it can be observed that the behavior of the correlation is completely different; from 2012 onwards, the correlations show a negative trend until they reach their lowest point in 2014, before only slightly rising again.

Table 4. Descriptive statistics for correlations

\begin{tabular}{lc|c|c}
\hline \multicolumn{1}{c|}{ Statistic } & GFC period & EDC period \\
\hline Mean & 0.5524 & 0.5066 \\
Maximum & 0.9020 & 0.9401 \\
Minimum & -0.2288 & -0.1519 \\
Std. Dev. & 0.2999 & 0.3512 \\
Skewness & -0.7417 & -0.4168 \\
\hline Kurtosis & -0.6474 & -1.4606 & 156.13 \\
Jarque-Bera & 132.62 & {$[0.0000]$} \\
\hline Probability & {$[0.0000]$} & \\
\hline
\end{tabular}




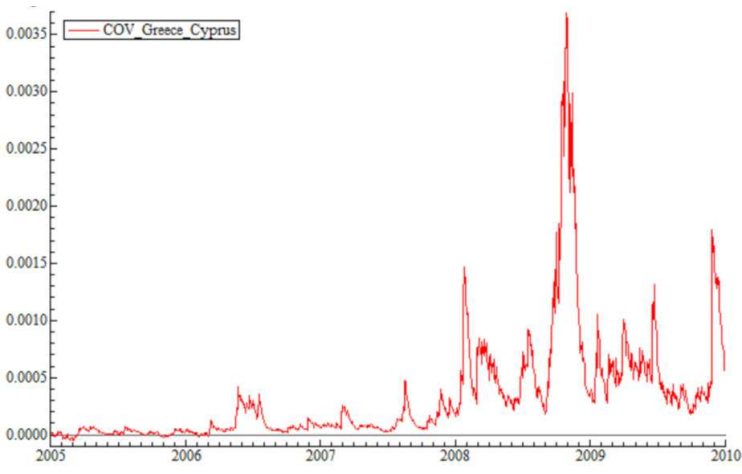

Figure 5. GFC covariance

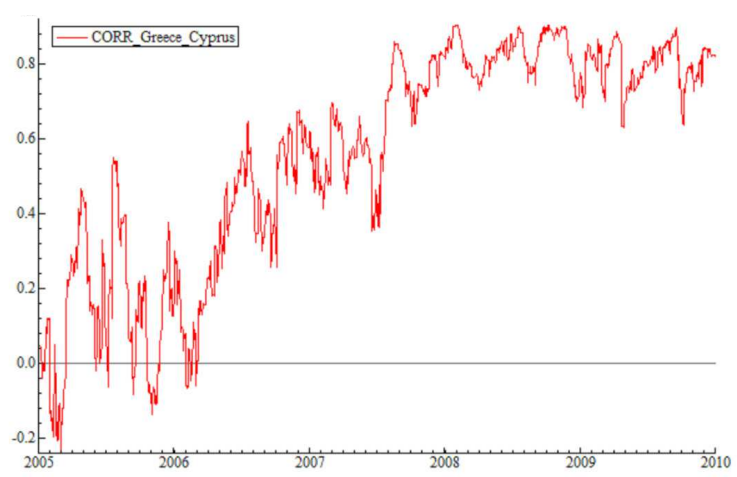

Figure 7. GFC correlations

The two crises are faced differently by the Eurozone since the Greek case was still underway when the Cypriot crises erupted. Besides, the nature of the problems and the structure of the economies were vastly different. Thus, the Cyprus case was a great opportunity to test-run the bail-in solution, turning the depositors into bank shareholders. However, the risk for Europe lays on Greek instability, which could be deepened by the interdependence of the two economies. However, by 2013 this interdependence was significantly decreased (Figures 6 and 8), and, thus, it was now easier to implement the bail-in in a shielded environment. It is clear that Cyprus, being a small economy, whose financial ties with the Eurozone were hindered, was an ideal case for a test implementation of bail-in, which, it should be noted, has since been adopted as the go-to solution for banking distress.

\section{DISCUSSION}

As a member of the European Economic Community (EEC) from 1981, Greece enjoyed several advantages through development programs provided by the European Union. During the last

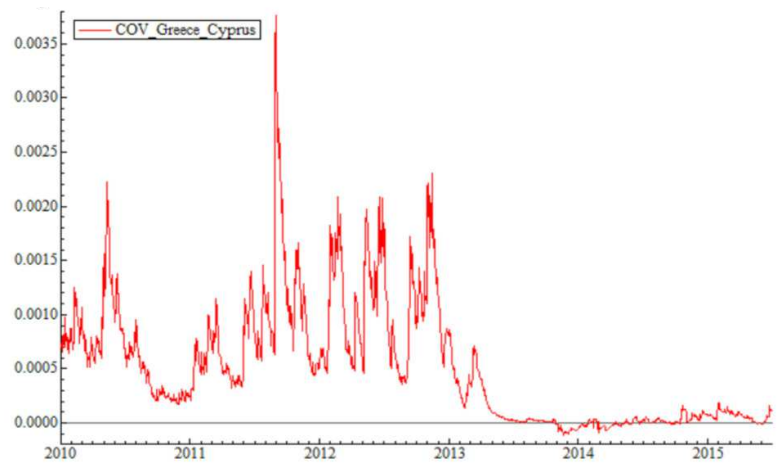

Figure 6. EDC covariance

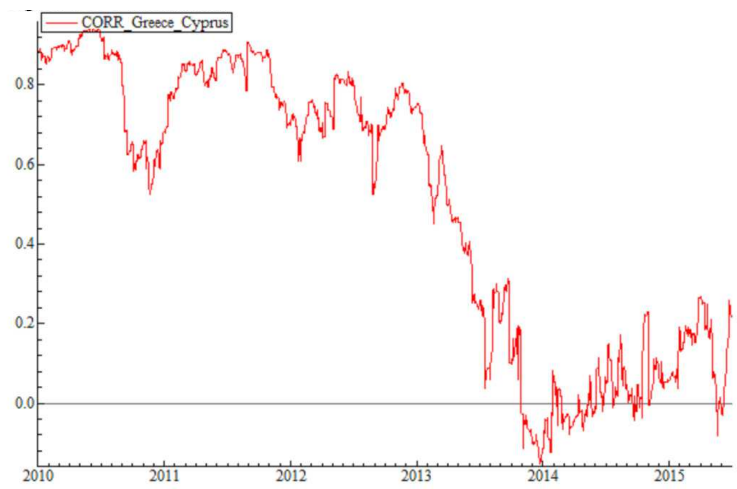

Figure 8. EDC correlations

decade, government policies led to a significant public deficit due to the inefficient management of the development programs. The 2004 Olympic Games and the non-productive public sector increased the country's obligations. These needs were financed by bonds, the return on investment ratio that was not adequate to cover the country's costs. Tax evasion and political corruption led the country to a financial dead end. The 2008 Global Financial Crisis revealed these problems in the Greek economy and alerted hedge funds and major credit rating firms that focused on the Greek economy and its declining debt-worthiness. Although the Eurozone seemed to be well secured, credit default swaps (CDS) focused on Greece. The consequences of these events forced the Greek government to implement a series of harsh austerity measures to decrease its deficit and debt, which at the end of 2009, according to Eurostat, were $15.2 \%$ and $126.8 \%$ of GDP, respectively (Figure 9).

The situation in Greece has since been characterized by an economic impasse, with rising unemployment and significant liquidity problems in the banking sector. However, some of the core issues of cooperation among the EU members did not 
Source: Eurostat.

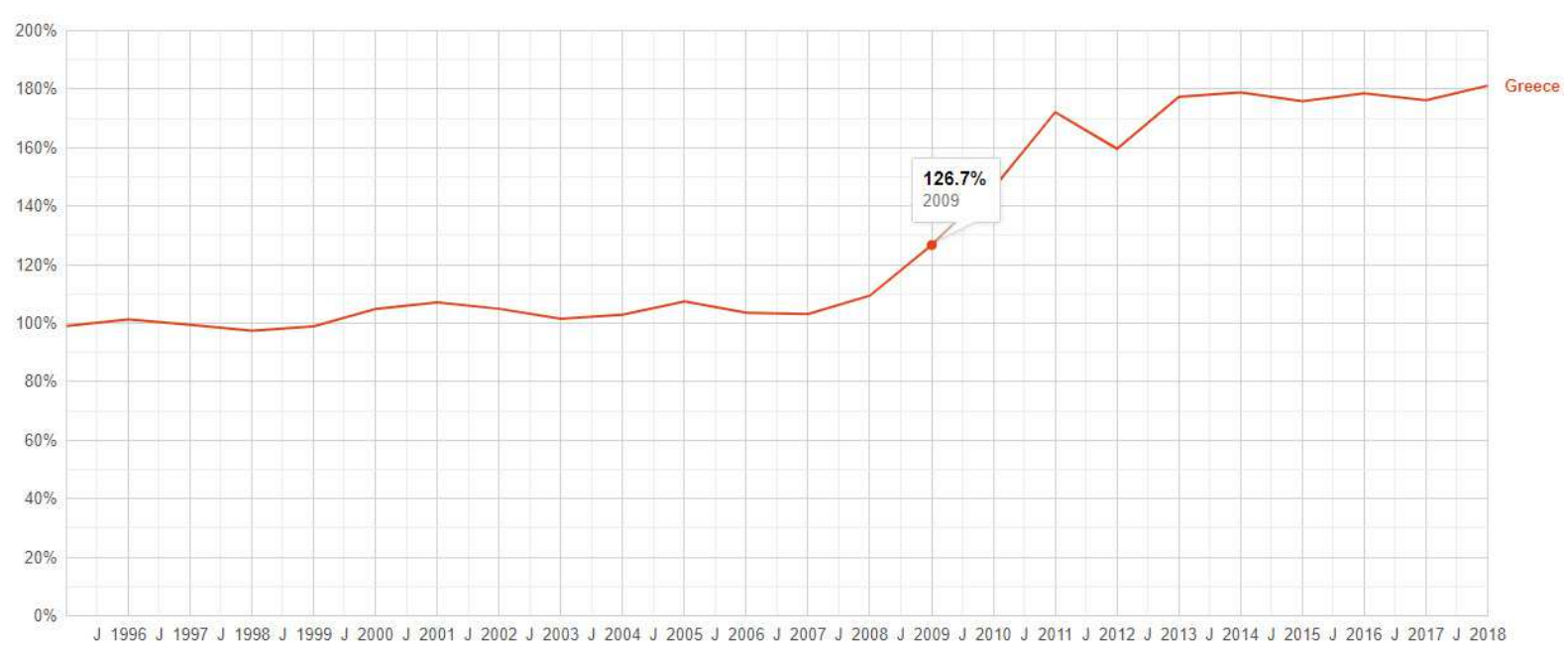

Figure 9. Greek government debt as a percent of GDP

help achieve a swift response, and, thus, volatility remained in the European economic environment. Investors who bet on the Eurozone collapse took advantage of the conflicting interests between its members and increased the pressure on countries with high debt and deficits. This resulted in a debt crisis for South European countries and Ireland, which was nightmarish for Greece and the Eurozone as a whole. For Greece, the crisis was deepened by the inefficient banking sector (Christopoulos et al., 2020) and corruption and the poor functioning of government institutions
(Policardo \& Carrera, 2018). Additionally, markets were still restless due to the global recession that followed the US subprime crisis. Many other countries, including Belgium, UK, and France, faced high debts and deficits. This resulted in an extended recession in the Eurozone.

Following the Greek debt crisis, Cyprus was hit by the domino effect of negative consequences. As can be seen from Figure 10, the Cypriot economy passed into a recessionary stage after 2009. The country seemed to be well secured at the begin-

Source: World Bank, ECB.

\section{Government Debt as \% of GDP}

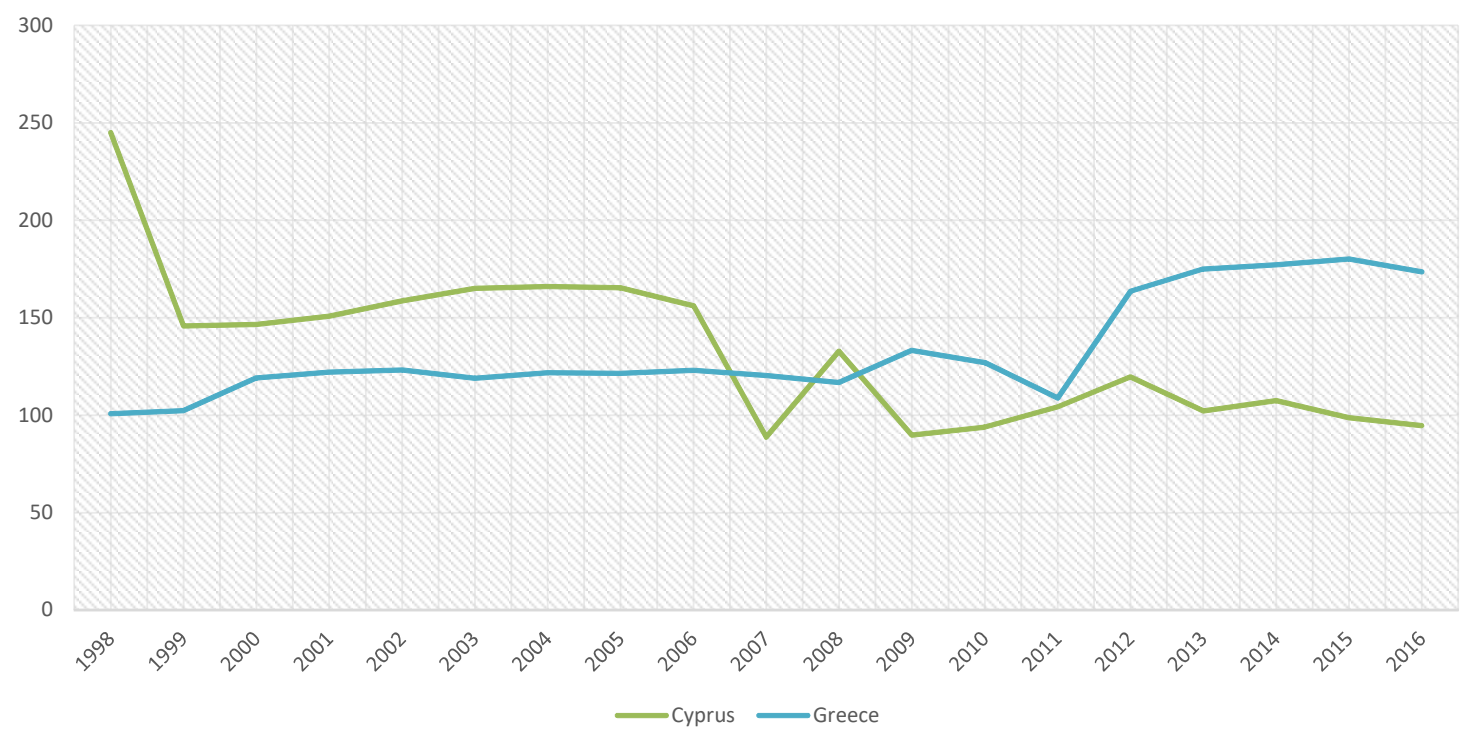

Figure 10. Greek and Cypriot government debt as \% of GDP 
ning of the subprime crisis, but then a huge debt crisis was triggered, which surpassed the average level of the Eurozone. Some of these reasons were non-performing loans, the exposure to the haircut of the Greek government bonds, and the inability to raise liquidity from the markets to support the financial sector. This resulted in an increase in unemployment and a steep deterioration in output in the tourism and shipping sectors. Consequently, commercial properties declined by almost 30\%, and the banking sector faced liquidity problems from the exposure (EUR 22 billion) to the Greek private sector. The Cyprus crisis was different from the Greek crisis as the initial problem was the banking sector.

Cyprus had a very low tax rate and has thus attracted many foreign investors, including many Russians. As credit rating firms gradually downgraded their ratings for the Cypriot economy and the liquidity problem came to surface, Russia offered an emergency loan of EUR 2.5 billion (at a $4.5 \%$ interest rate) to Cyprus to cover its financial gap through the international markets. Unfortunately, this solution did not solve the problem since the loan did not include any funds for the recapitalization of the banking sector after the haircut of the Greek government bonds. The multiple rating downgrades of the Cyprus economy led to financial suffocation and a liquidity gap, which forced the government to ask for a bailout from the European Financial Stability Facility (EFSF) on 25 June 2012. After several negotiations with European regulators, they agreed for a bailout of EUR 10 billion on 25 March 2013. In return, Cyprus had to impose a $40 \%$ bank deposit levy on all uninsured deposits above EUR 100,000 and merge its second-largest commercial bank, Laiki Bank, into the largest commercial bank, the Bank of Cyprus. The progression of events justifies the criticism imposes by some researchers that the Eurozone was inherently unstable and would bring about significant debt crises due to asymmetric effects (Beckworth, 2017).

The core issue of the Eurozone in the Greek Debt crisis was whether a small country that covers $2.5 \%$ of the Eurozone's GDP could affect the whole European region. This possible scenario forced the Eurozone and the IMF to focus more on this direction. In the meantime, most developed economies were struggling to recover from the subprime crisis and hedge the risk from the exposure. The involved and exposed stakeholders tried to confront the threat at an early stage. Greece government adopted many austerity measures (such as a $10 \%$ cut to bonuses, freezes in public-sector salaries, and increases in VAT) to increase savings and reduce the high government deficit. Unfortunately, the measures were not enough, and the recession deepened even more while consumption decreased rapidly, and the government was unable at this stage to stabilize tax revenue. All the upcoming rescue packages did not change the financial condition in Greece; tax collection inefficiency and delays in the public sector's reconstruction were the biggest challenges. Eurozone presented a significant inability to successfully resolve the problem in Greece, creating serious doubts about the effectiveness of the program. Shortly after, the Eurozone felt the pressure from the credit rating firms. Hence, in January 2012, Standard \& Poor's downgraded France (from AAA rating to AA+), and this was the first shock in the Eurozone area.

As for the Cypriot financial crisis, the applied bail-in model affected only the domestic economy while the spillover effects to other countries were significantly low. It was assumed that the program of Cyprus was ineffective in the first place because even three years after the applied measures, the Cypriot economy presented negative GDP growth and persistently high unemployment. On the other hand, major economies and investors had a great opportunity to implement a new model in a small country with low transmission effects. The economy of Cyprus had a significant, well-organized banking sector, compared to the size of the country, and foreigners (including many Russian investors) had placed large amounts of money in the local economy. Besides, the country invested a lot in exploring natural gas in the maritime exclusive economic zone, and the agreements with Israel and the USA were the next great challenge to lead the economy to develop.

The austerity measures implemented in Greece did not provide any flexibility to increase the GDP and simultaneously decrease the deficit to a sustainable level. This was the first time a Eurozone country faced such a severe financial crisis that was intercorrelated with the unified 
currency. The threat of financial contagion led the members of the Eurozone and investors and governments to study and carefully monitor the possibility of a domino effect from Greece to other countries or channels of the economy, especially that period after the 2009 and beginning of the European Debt crisis. In case of a "Grexit," some may have anticipated great losses to several major economies, which would be difficult to calculate that period. In the pessimistic scenario, the EU could face several attempts from its members to withdraw from the Eurozone area, with the rest of the PIIGS countries being the first in line. The pending (at the time) decision for Brexit deepened this risk (Polyzos et al., 2020). Despite claims and reassurances from EU policymakers that the financial condition in the Eurozone was tranquil, stock markets were strongly interconnected with rumors and negative information. Thus, a possible domino effect was feasible and persisted long before the stability gained ground. It is reasonable to conclude that the Greek debt crisis was similar to Italy and Portugal, while the banking crisis in Cyprus resembles those of Ireland, Spain, and Iceland.

\section{CONCLUSION}

In this study, a DCC model was applied to study interdependence during the Greek debt crisis and the Cypriot financial crisis. In line with existing literature (Suleman et al., 2017), the paper's findings show increased volatility during the outbreak of the two crises. The current work also shows that the correlation between the two stock markets was strong and increased up to approximately 2013. However, after the emergence of the Cyprus banking crisis, this correlation was significantly decreased. These findings are in line with similar literature on the topic (Samitas \& Kampouris, 2019).

Following this, the European authorities chose to implement the bail-in solution to the Cypriot crisis to test the results in a protected environment. As a small country and economy, Cyprus seemed to not have the power to produce spillover effects on bigger economies, except through the Greek economy. Since the correlation with Greece was decreased, the path was henceforth open. Therefore, it can be assumed that Cyprus was used as a test case to measure the effectiveness of bail-ins as a solution to banking sector stress, without the risk of further impact on the Eurozone. Besides, the implementation of the bailins served as a deterrent for banks and local authorities alike to avoid risky behavior or loose banking oversight.

In terms of suggestions to policymakers, the outcome of the experiment seems to be successful. The bail-in solution was tested, and, despite the hard consequences for both the Cypriot and the Greek economies, the effects on the rest of the Eurozone were minimal. The bail-in was deemed successful and thus was adopted by the European authorities to the preferred solution when banks are under duress, although other studies (e.g., Samitas \& Polyzos, 2015) have not supported a positive outcome in all scenarios. However, the results show how policy measures can also effectively reduce the interdependence of small economies, even in cases where there are strong historical ties. This could suggest that other small economies in Europe are, potentially, at risk of being used as test cases for new measures, particularly if they display strong interdependence with only one small European economy. If governments are to protect their local economies from such experiments, diversification of economic ties is the proposed solution. This could be of particular interest to the currently developing economies of Central Europe.

\section{AUTHOR CONTRIBUTIONS}

Conceptualization: Aristeidis Samitas, Elias Kampouris.

Data curation: Elias Kampouris.

Formal analysis: Elias Kampouris.

Investigation: Aristeidis Samitas, Elias Kampouris, Stathis Polyzos. 
Methodology: Aristeidis Samitas, Elias Kampouris, Stathis Polyzos.

Project administration: Aristeidis Samitas.

Resources: Anastasia Ef. Spyridou.

Software: Anastasia Ef. Spyridou.

Supervision: Aristeidis Samitas.

Validation: Elias Kampouris, Stathis Polyzos.

Visualization: Elias Kampouris.

Writing - original draft: Elias Kampouris.

Writing - review \& editing: Aristeidis Samitas, Elias Kampouris, Stathis Polyzos, Anastasia Ef. Spyridou.

\section{REFERENCES}

1. Ahmad, W., Sehgal, S., \& Bhanumurthy, N. R. (2013). Eurozone crisis and BRIICKS stock markets: Contagion or market interdependence? Economic Modelling, 33, 209-225. https://doi.org/10.1016/j.econmod.2013.04.009

2. Aielli, G. P. (2013). Dynamic conditional correlation: on properties and estimation. Journal of Business \& Economic Statistics, 31(3), 282-299. https://dx.doi. org/10.2139/ssrn.1507743

3. Anastasopoulos, A. (2018). Testing for financial contagion: New evidence from the Greek crisis and yuan devaluation. Research in International Business and Finance, 45, 499-511. https://doi. org/10.1016/j.ribaf.2017.09.001

4. Anufriev, M., Radi, D., \& Tramontana, F. (2018). Some reflections on past and future of nonlinear dynamics in economics and finance. Decisions in Economics and Finance, 41(2), 91-118. Retrieved from https:// link.springer.com/article/10.1007/ s10203-018-0229-9

5. Beckworth, D. (2017). The monetary policy origins of the eurozone crisis. International Finance, 20(2), 114-134. https:// doi.org/10.1111/infi.12110

6. Bekiros, S. (2014). Contagion, decoupling and the spillover effects of the US financial crisis: Evidence from the BRIC markets. International Review of Financial Analysis, 33, 58-69. https://doi. org/10.1016/j.irfa.2013.07.007

7. Billio, M., \& Pelizzon, L. (2003). Contagion and interdependence in stock markets: have they been misdiagnosed? Journal of Economics and Business, 55, 405-426. https://doi.org/10.1016/ S0148-6195(03)00048-1

8. Bollerslev, T. (1990). Modelling the coherence in short-run nominal exchange rates: a multivariate generalized ARCH model. Review of Economics and Statistics, 72, 498-505. Retrieved from https://www.jstor.org/ stable $/ 2109358$ ? seq $=1$

9. Calvo, S., \& Reinhart, C. (1996). Capital flows to Latin America: is there evidence of contagion effects? In G. A. Calvo, M. Goldstein, \& E. Hochreiter (Eds.), Private Capital Flows to Emerging Markets after the Mexican Crisis (pp. 151-171). Institute for International Economics, Washington, DC. Retrieved from https://ideas.repec.org/p/wbk/ wbrwps/1619.html

10. Cappiello, L., Engle, R. H., \& Sheppard, K. (2006). Asymmetric dynamics in the correlations of global equity and bond returns. Journal of Financial Econometrics, 4, 537-572. https:// doi.org/10.1093/jjinec/nbl005

11. Castagneto-Gissey, G., \& Nivorozhkin, E. (2016). No contagion from Russia toward global equity markets after the 2014 international sanctions. Economic Analysis and Policy, 52, 79-98. https://doi.org/10.1016/j. eap.2016.08.006

12. Celık, S. (2012). The more contagion effect on emerging markets: The evidence of DCCGARCH model. Economic Modelling, 29, 1946-1959. https://doi.org/10.1016/j.econmod.2012.06.011

13. Chiang, T. H., Li, J., \& Yang, S. Y. (2014). Dynamic stock-bond return correlations and financial market uncertainty. Review of Quantitative Finance and Accounting, 45(1), 1-30. Retrieved from https://www.researchgate. net/publication/272017077_Dynamic_stock-bond_return_correlations_and_financial_market_uncertainty

14. Christopoulos, A. G., Dokas, I. G., Katsimardou, S., \& Spyromitros, E. (2020). Assessing banking sectors' efficiency of financially troubled Eurozone countries. Research in International Business and Finance, 52. https://doi.org/10.1016/j. ribaf.2019.10112

15. Cho, J. H., \& Parhizgari, A. M. (2009). East Asian financial contagion under DCCGARCH. International Journal of Banking and Finance, 6(1), 17-30. Retrieved from https:// www.researchgate.net/publication/41459000_East_Asian_Financial_Contagion_under_DCCGarch

16. Corsetti, G., Pericoli, M., \& Sbracia, M. (2005). Some contagion, some interdependence: more pitfalls in tests of financial contagion. Journal of International Money and Finance, 24, 1177-1199. Retrieved from https://papers.ssrn. com/sol3/papers.cfm?abstract_ $\mathrm{id}=311440$

17. Dimitriou, D., Kenourgios, D., \& Simos, T. (2013). Global financial crisis and emerging stock market contagion: A multivariate 
FIAPARCH-DCC approach. International Review of Financial Analysis, 30, 46-56. Retrieved from https://www.researchgate.net/publication/256840686_Global_financial_crisis_and_emerging_stock_ market_contagion_A_multivariate_FIAPARCH-DCC_approach

18. Dungey, M., \& Martin, V. L. (2007). Unravelling Financial Market Linkages during Crises. Journal of Applied Econometrics, 22, 89-119. Retrieved from http:// dungey.bigpondhosting.com/pdfs/ nyse_oct05.pdf

19. Engle, R. F. (2002). A dynamic conditional correlation: a simple class of multivariate generalized autoregressive conditional heteroskedasticity models. Journal of Business \& Economic Statistics, 20(3), 339-350. Retrieved from https://www.jstor.org/ stable/1392121?seq $=1$

20. Gjika, D., \& Horváth, R. (2013). Stock Market Co-movements in Central Europe: Evidence from the Asymmetric DCC Model. Economic Modelling, 33, 55-64. Retrieved from https://econpapers. repec.org/article/eeeecmode/v_3a33_3ay_3a2013_3ai_3ac_3ap_ 3a55-64.htm

21. Glosten, L. R., Jagannathan, R., \& Runkle, D. E. (1993). On The Relation between The Expected Value and The Volatility of Nominal Excess Return on stocks. Journal of Finance, 48, 1779-1801. Retrieved from https://faculty. washington.edu/ezivot/econ589/ GJRJOF1993.pdf

22. Gupta, R., \& Donleavy, G. D. (2009). Benefits of diversifying investments into emerging markets with time varying correlations: an Australian perspective. Journal of Multinational Financial Management, 19, 160-177. https://doi.org/10.1016/j.mulfin.2008.10.001

23. Hemche, O., Jawadi, F., Maliki, S. B., \& Cheffou, A. I. (2016). On the study of contagion in the context of the subprime crisis: A dynamic conditional correlationmultivariate GARCH approach. Economic Modelling, 52, 292-299.
Retrieved from https://www. semanticscholar.org/paper/Onthe-study-of-contagion-in-thecontext-of-the-A-Hemche-Jawadi/ 5c8f812af8d0c09a0b479e6a5140a2 cf03c31e90

24. Huidrom, R., Kose, M. A., \& Ohnsorge, F. L. (2017). How important are spillovers from major emerging markets. International Finance, 23, 47-63. https://doi. org/10.1111/infi.12350

25. Hwang, J.-K. (2014). Spillover Effects of the 2008 Financial Crisis in Latin America Stock Markets. International Advances in Economic Research, 20(3), 311-324. Retrieved from https:// link.springer.com/article/10.1007/ s11294-014-9472-1

26. Jithendranathan, T. (2005). Time varying correlations of U.S. and Russian equity returns. Investment Management and Financial Innovations, 4, 69-79. Retrieved from https://ideas.repec.org/p/ wpa/wuwpif/0403006.html

27. Karanasos, M., Yfanti, S., \& Karoglou, M. (2016). Multivariate FIAPARCH modelling of financial markets with dynamic correlations in times of crisis. International Review of Financial Analysis, 45, 332-349. https://doi. org/10.1016/j.irfa.2014.09.002

28. Kazi, I. A., \& Wagan, H. (2014). Are emerging markets exposed to contagion from U.S.: Evidence from stock and sovereign bond markets (Working Papers 2014058). Department of Research, Ipag Business School. Retrieved from https://www.researchgate. net/publication/285437716_Are_ Emerging_Markets_Exposed_to_ Contagion_from_the_United_ States_Evidence_from_Stock_and_ Sovereign_Bond_Markets

29. Kenourgios, D. (2014). On financial contagion and implied market volatility. International Review of Financial Analysis, 34, 21-30. https://doi.org/10.1016/j. irfa.2014.05.001

30. Kenourgios, D., \& Dimitriou, D. (2014). Contagion of the Global Financial Crisis and the real economy: A regional analysis. Economic Modelling, 44, 283-293. https://doi.org/10.1016/j.econmod.2014.10.048

31. Kim, B. H., \& Kim, S. (2013). Transmission of the global financial crisis to Korea. Journal of Policy Modeling, 35, 339-353. https://doi.org/10.1016/j.jpolmod.2012.01.005

32. King, M., \& Wadhwani, S. (1990). Transmission of volatility between stock markets. Review of Financial Studies, 3, 5-33. Retrieved from https://www.jstor.org/ stable $/ 2961954$ ? seq $=1$

33. Lee, S., \& Kim, K. (1993). Does the October 1987 crash strengthen the co-movements among national stock markets? Review of Financial Economics, 3, 89-102. Retrieved from https://go.gale. $\mathrm{com} / \mathrm{ps} /$ anonymous?id=GALE $\% 7$ CA16637672\&sid=googleScholar $\& v=2.1 \& i t=r \&$ linkaccess $=$ abs\&iss $\mathrm{n}=10583300 \& \mathrm{p}=\mathrm{AONE} \& \mathrm{sw}=\mathrm{w}$

34. Liow, K. H. (2012). Comovements and Correlations Across Asian Securitized Real Estate and Stock Markets. Real Estate Economics, 40(1), 97-129. https://doi.org/10.1111/j.15406229.2011.00314.x

35. McDonald, R., Sogiakas, V., \& Tsopanakis, A. (2015). An investigation of systemic stress and interdependencies within the Eurozone and Euro Area countries. Economic Modelling, 48, 52-69. https://doi.org/10.1016/j. econmod.2014.10.023

36. Pantos, T., Polyzos, S., Armenatzoglou, A., \& Kampouris, E. (2019). Volatility Spillovers in Electricity Markets: Evidence from the United States. International Journal of Energy Economics and Policy, 9(4), 131-143. Retrieved from https://www.econjournals. com/index.php/ijeep/article/ view/7563

37. Pesaran, M. H., \& Pesaran, B. (2007). Modelling Volatilities and Conditional Correlations in Futures Markets with a Multivariate $t$ Distribution (Working Paper). Retrieved from https://www.iza. org/publications/dp/2906/modelling-volatilities-and-conditionalcorrelations-in-futures-marketswith-a-multivariate-t-distribution 
38. Petmezas, D., \& Santamaria, D. (2014). Investor induced contagion during the banking and European sovereign debt crisis of 2007e2012: Wealth effect or portfolio rebalancing? Journal of International Money and Finance, 49, 401-424. Retrieved from https://ideas.repec.org/a/eee/jimfin/v49y2014ipbp401-424.html

39. Policardo, L., \& Carrera, E. J. S. (2018). Corruption causes inequality, or is it the other way around? An empirical investigation for a panel of countries. Economic Analysis and Policy, 59, 92-102. https://doi. org/10.1016/j.eap.2018.05.001

40. Polyzos, S., Abdulrahman, K., \& Christopoulos, A. (2018). Good management or good finances? An agent-based study on the causes of bank failure. Banks \& Bank Systems, 13(3), 95-105. http://dx.doi.org/10.21511/ bbs.13(3).2018.09

41. Polyzos, S., Samitas, A., \& Katsaiti, M. S. (2020). Who is unhappy for Brexit? A machinelearning, agent-based study on financial instability. International Review of Financial Analysis, 72, 101590. https://doi.org/10.1016/j. irfa.2020.101590

42. Rajwani, S., \& Kumar, D. (2015). A Dynamic Conditional Correlation Analysis-Based Approach to Test Financial Contagion in Developing Markets. In Managing in Recovering Markets Springer Proceedings in Business and Economics (pp. 1-13). Retrieved from https://www.researchgate. net/publication/312736658_A_ Dynamic_Conditional_Correlation_Analysis-Based_Approach_ to_Test_Financial_Contagion_in_ Developing_Markets

43. Rigobon, R., \& Sack, B. (2003). Spillovers across US financial markets (No. w9640). National Bureau of Economic Research.

44. Samitas, A., \& Kampouris, E. (2019). Financial illness and political virus: the case of contagious crises in the Eurozone. International Review of Applied Economics, 33(2), 209-227. Retrieved from https://www.researchgate.net/ publication/320933657_Financial_illness_and_political_virus_the_case_of_contagious_crises in the Eurozone

45. Samitas, A., \& Polyzos, S. (2015). To Basel or not to Basel? Banking crises and contagion. Journal of Financial Regulation and Compliance, 23(3), 298-318. https://doi.org/10.1108/JFRC-112014-0045

46. Samitas, A., \& Polyzos, S. (2016). Freeing Greece from capital controls: Were the restrictions enforced in time? Research in International Business and Finance, 37, 196-213. https://doi. org/10.1016/j.ribaf.2015.11.005

47. Samitas, A. Kampouris, E., \& Zaghum, U. (2020). Financial contagion in real economy: The key role of policy uncertainty. International Journal of Finance \& Economics. https://doi. org/10.1002/ijfe.2235

48. Sikhosana, A., \& Aye, G. C. (2018). Asymmetric volatility transmission between the real exchange rate and stock returns in South Africa. Economic Analysis and Policy, 60, 1-8. https://doi. org/10.1016/j.eap.2018.08.002

49. Suleman, T., Gupta, R., \& Balcilar, M. (2017). Does country risks predict stock returns and volatility? Evidence from a nonparametric approach. Research in International Business and Finance, 42, 1173-1195. Retrieved from https://www.researchgate. net/publication/318652979_Does_ Country_Risks_Predict_Stock_ Returns_and_Volatility_Evidence_ from_a_Nonparametric_Approach

50. Tamakoshi, G., \& Hamori, S. (2013). An asymmetric dynamic conditional correlation analysis of linkages of European financial institutions during the Greek sovereign debt crisis. The European Journal of Finance, 19(10), 939-950. https://doi.org/10 .1080/1351847X.2012.712921

51. Wang, K. M. (2013). Did Vietnam stock market avoid the "contagion risk" from China and the U.S.? The contagion effect test with dynamic correlation coefficients. Quality \& Quantity June, 47(4), 2143-2161. Retrieved from https:// link.springer.com/article/10.1007/ s11135-011-9647-2

52. Zhou, J., \& Gao, Y. (2012). Tail Dependence in International Real Estate Securities Markets. Journal of Real Estate Finance and Economics, 45(1). Retrieved from https://link.springer.com/article/10.1007/s11146-010-9249-0

53. Zimmer, D. (2014). Asymmetric dependence in house prices: evidence from USA and international data. Empirical Economics Journal, 181. https://doi. org/10.1007/s00181-014-0859-x 